\title{
Peran Keluarga Pasien dalam Mencegah Kejadian Tidak Diharapkan pada Pasien
}

\section{Lili Evalina}

\section{lili.evalina@gmail.com}

\section{Latar Belakang}

Keluarga merupakan peran penting dalam setiap kehidupan seseorang karena keluarga merupakan institusi yang memberikan kesejahteraan, rasa aman, pendidikan dasar, dan pengasuhan sehingga keluargalah merupakan institusi terdekat untuk setiap orang. Menurut Bailon dan Magalya (1978) keluarga adalah dua atau lebih individu yang hidup dalam satu rumah tangga karena adanya hubungan darah ,perkawinan atau adopsi. Mereka saling berinteraksi satu sama lain dan mempunyai peran masing-masing dan menciptakan serta mempertahankan suatu budaya.

Fungsi keluarga sendiri terdiri dari fungsi pengaturan seksual , fungsi reproduksi, fungsi sosialisasi atau memberikan contoh yang baik, fungsi afeksi atau rasa kasih sayang, fungsi afeksi merupakan hal yang penting karena dengan adanya rasa kasih saying seseorang akan merasa dirinya berharga karena dia merasa dihargai dan dicintai , fungsi penentuan status, fungsi perlindungan, dan fungsi ekonomis. Semua fungsi ini sangat berguna untuk saling mendukung satu sama lain terutama saat salah satu anggota keluarga jatuh sakit atau terserang suatu penyakit.

Penyakit itu sendiri membawa dampak pada pasien baik dari segi fisik maupun psikologis pada pasien yang dicemaskan akan semakin memperkeruh keadaan pasien. Maka dari itu, untuk menghindari hal-hal yang tidak diinginkan keselamatan pasien merupakan hal yang utama untuk pihak rumah sakit maupun pihak keluarga karena hal ini berguna untuk memberikan rasa aman dan nyaman kepada pasien dalam hal perawatan oleh rumah sakit dan hal mental atau psikologis dari keluarga.

Berdasarkan penelitian yang dilakukan oleh sekelompok orang yang berasal dari WHO (2004) yaitu The World Health Organization Quality Life, mereka meneliti tentang penilaian kualitas hidup. Mereka melakukan penilaian melalui empat hal yaitu kondisi fisik, psikologis, hubungan sosial, dan lingkungan individu. Berdasarkan hasilnya disimpulkan bahwa kualitas hidup seseorang tidak didapatkan dengan sendirinya tetapi berasal dari berbagai faktor di sekitar mereka terutama adalah keluarga. 
Keluarga sangat berperan dalam memberikan dorongan semangat atau dukungan bagi mental para pasien agar keinginan mereka untuk sembuh lebih tinggi. Selain itu, fungsi afeksi dengan memberikan perhatian dan kasih sayang dalam mengawasi pasien dapat mengurangi resiko untuk hal-hal yang tidak diinginkan karena selalu dalam pengawasan.

Kerap kali keterbatasan tenaga medis yang ada membuat tenaga medis tidak dapat mengontrol setiap detik pasien yang terdapat pada rumah sakit itu dan dari situlah keluarga berfungsi untuk membantu tenaga medis dalam menjaga dan mengawasi pasien agar terus termonitor dan mengurangi kemungkinan terjadinya hal yang tidak diinginkan.

\section{Metode}

Metode yang dilakukan adalah dengan menggunakan penelitian yang sudah ada atau sudah dilakukan oleh para peneliti baik secara kuantitatif maupun kualitatif dan dituangkan melalui jurnal-jurnal atau artikel yang mereka terbitkan. Jurnal-jurnal dan artikel yang digunakan merupakan jurnal-jurnal dan artikel yang terpercaya sehingga dapat dijadikan dasar pembuatan yang memiliki kebenaran dan validitas yang tinggi.

Hasil penggabungan dari jurnal-jurnal dan artikel-artikel yang telah diperoleh akan dijadikan acuan untuk membuat makalah ini. Pada makalah ini kita akan mengetahui dan mempelajari peran sebuah keluarga dalam mencegah kejadian yang tidak diharapkan pada pasien.

\section{Hasil}

Hasil yang dapat disimpulkan adalah kualitas hidup dari setiap orang merupakan hal yang sangat penting karena kualitas hidup juga menyangkut akan kesehatan dari setiap pribadi dan yang mempengaruhi kualitas hidup seseorang adalah kondisi fisik, psikologis, hubungan sosial, dan lingkungan individu sehingga kualitas hidup seseorang sangat dipengaruhi oleh keluarga atau lingkungan terdekat mereka.

Fisik yang sehat dan kualitas hidup yang baik merupakan keinginan dari setiap orang tetapi tidak dapat kita hindari bahwa siapa saja dapat terserang dalam suatu penyakit mulai dari penyakit yang ringan hingga berbahaya. Segala jenis penyakit yang dihadapi oleh pasien perlu dilakukan pengawasan agar tidak terjadi hal-hal yang tidak diinginkan.

Melihat betapa pentingnya rasa aman dan nyaman terhadap pasien maka WHO dan mentri kesehatan Indonesia menegaskan untuk melakukan patient safety yang dilakukan oleh tenaga medis untuk meminimalkan hal-hal yang tidak diinginkan. Dalam hal keamanan 
pasien atau patient safety yang berperan aktif bukan hanya pihak medis atau dokter tetapi peran dari pihak keluarga juga sangat dibutuhkan.

Keluarga sebagai pihak yang terdekat pada pasien tentunya menginginkan hal-hal yang positif dan menginginkan bahwa pasien segera sembuh dan terhindar dari hal-hal yang tidak diinginkan . Maka dari itu, keluarga memiliki peran dalam memberikan dukungan baik secara fisik, mental, dan financial bagi pasien,meskipun tidak dapat dihindari bahwa terkadang pihak keluarga pun merasa sedih dan terpuruk ketika keluarganya terkena suatu penyakit yang tidak diinginkan.

Keluarga memberikan fungsi-fungsi yang seharusnya sudah diterapkan dalam lingkungan keluarga terutama fungsi afeksi dimana memberikan rasa kasih sayang terhadap pasien yang sedang mengalami sakit sehingga dengan adanya rasa kasih sayang membuat pasien lebih merasa dirinya berharga dan layak untuk bisa sembuh dan beraktivitas kembali.

Fungsi selanjutnya adalah fungsi perlindungan sebagai keluarga sudah seharusnya dapat saling melindungi satu sama lain terutama melindungi pihak keluarga yang sedang membutuhkan perlindungan dan perhatian lebih . Perlindungan tersebut dapat mencegah halhal yang tidak diinginkan karena pihak keluarga yang melakukan perlindungan melalui pengawasan ekstra terhadap keluarga yang terkena suatu penyakit.

Beberapa cara dapat dilakukan oleh pihak keluarga untuk dapat meminimalisir dan mencegah hal yang tidak diinginkan pada pasien diantaranya adalah bersikap tenang dan tidak panik, memberikan dukungan dan motivasi untuk pasien, melakukan pengawasan secara rutin , mempelajari dan konsultasi terhadap pihak medis dan dokter, komunikasi yang baik dan efektif antar keluarga .

\section{Pembahasan}

Keluarga merupakan lingkungan terdekat dari setiap orang. Maka keluarga memiliki fungsi-fungsi dalam membimbing antar keluarga satu sama lain dan masing-masing keluarga tentunya memiliki perannya masing-masing dalam keluarga. Menurut Bailon dan Magalya (1978) keluarga adalah dua atau lebih individu yang hidup dalam satu rumah tangga karena adanya hubungandarah, perkawinan atau adopsi. Mereka saling berinteraksi satu sama lain dan mempunyai peran masing-masing dan menciptakan serta mempertahankan suatu budaya.

Fungsi tersebut diantaranya adalah fungsi pengaturan seksual , fungsi reproduksi , fungsi sosialisasi ,fungsi afeksi, fungsi pemberian status , fungsi perlindungan, dan fungsi ekonomis. Seluruh fungsi ini dapat berperan untuk penanaman nilai yang dapat diterapakan dalam kehidupan sehari-hari. 
Keluarga sangat berperan penting dalam kesehatan antar anggota keluarganya kesehatan tersebut merupakan kesehatan fisik maupun mental. Maka dari itu, kualitas hidup dari seseorang sangat bergantung dari bagaimana lingkungan keluarga tersebut bersikap kepada tiap individu di dalam suatu keluarga.

Menurut Smilkstein pada tahun 1978 penilaian fungsi keluarga terhadap kualitas hidup seseorang dapat dilihat dari lima hal diantaranya adalah adaptasi, kemitraan atau partnership ,pertumbuhan, kasih sayang, dan kebersamaan.

Aspek adaptasia dalah dimana setiap anggota keluarga dapat beradaptasi dan membagi serta menggunakan sumber daya yang dimiliki, aspek kemitraan dimana belajar untuk bisa saling bertukar pendapat dan memecahkan masalah bersama, Aspek pertumbuhan dimana setiap anggota keluarga diberi kebebasan untuk dapat berkembang baik secara fisik maupun mental, aspek kasih saying adalah bagaimana setiap anggota keluarga dapat menunjukan emosi dan rasa sayang antar setiap keluarga, dan aspek kebersamaan bagaimana adanya waktu, keuangan, dan ruang yang dibagikan antar setiap keluarga . Jika aspek ini ada dalam keluarga maka kualitas hidup seseorang akan baik sehingga lebih besar kemungkinan terjadi hal-hal yang tidak diinginkan.

Kesehatan dan kualitas hidup setiap individu menjadi hal penting meskipun demikian tidak dapat dihindari bahwa setiap orang dapat terserang berbagai jenis penyakit mulai dari penyakit yang ringan hingga penyakit yang berat.

Melihat bahwa kesehatan tiap individu merupakan sesuatu yang berharga maka terdapat sebuah istilah keselamatan pasien atau patient safety. Menurut Departemen Kesehatan Republik Indonesia keselamatan pasien merupakan suatu system dimana rumah sakit membuat asuhan pasien lebih aman. Sistem tersebut meliputi assemen risiko, identifikasi dan pengelolahan hal yang berhubungan dengan risiko pasien, pelaporan dan analisis insiden, kemampuan belajar dari insiden dan tindak lanjutnya serta implementasi solusi untuk meminimalkan timbulnya risiko.

Sebagai keluarga pasti tidak menginginkan hal-hal diluar kendali terjadi terhadap pasien. Maka dari itu, keluarga juga berperan aktif dalam membantu tenaga medis untuk meminimalisir dan mencegah hal-hal yang tidak di inginkan kepada pasien.

Hal yang dapat dilakukan pertama kali adalah tetap tenang dan tidak panik . Kerap kali kita sebagai keluarga merasa panic ketika keluarga kita ada yang mengidap suatu penyakit . Hal ini merupakan respon yang wajar tetapi rasa cemas dan panik yang berlebihan tidak baik sebab akan semakin memperkeruh keadaan dan memungkinkan membuat kondisi pasien semakin menurun karena emosional yang ditampilkan oleh pihak keluarga. Jika kita 
bersikap tenang maka pasien juga akan lebih tenang dan dapat mengurangi pikiran negative dari pasien itu sendiri sehingga dapat mempercepat proses penyembuhan. Sikap panik juga dapat ditemukan dan disebabkan oleh hal lain seperti finansial yang harus di tanggung untuk proses perawatan pasien, dan berbagai masalah lainnya.

Selanjutnya adalah memberikan motivasi dan semangat kepada pasien . Motivasi dari orang terdekat pasien merupakan salah satu cara untuk mencegah hal-hal yang tidak diinginkan terhadap pasien karena dengan adanya motivasi pasien cenderung terpacu dan semangat untuk bisa mengembalikan keadaan seperti semula. Selain itu, pasien juga merasa bahwa dirinya dihargai dan diinginkan keberadaanya oleh keluarga. Motivasi dapat diberi bukan hanya dengan kata dan ucapan semangat tetapi juga dengan ketersediaanya waktu untuk mendengarkan keluh kesah serta memberikan solusi .

Peran lain yang dapat dilakukan oleh keluarga untuk mencegah kejadian yang tidak diinginkan terhadap pasien adalah melakukan pengawasan secara rutin , melakukan konsultasi terhadap pihak medis dan dokter. Pengawasan sangat perlu dilakukan terutama pengawasan terhadap keluarga yang sedang sakit . Pengawasan penting karena kita tidak pernah tahu hal tak terduga apa yang akan terjadi sehingga untuk mengantisipasinya melakukan pengawasan terhadap pasien merupakan salah satu caranya.

Melakukan konsultasi kepada pihak medis atau dokter dapat dengan melakukan pengecekan berkala, serta konsultasi perihal hal apa saja yang dapat dilakukan atau penanganan terhadap pasien jika sewaktu-waktu terjadi hal yang tidak diinginkan. Mempelajari jenis obat-obatan yang dikonsumsi oleh pasien serta prosedur-prosedur penting lainnya untuk membantu penyembuhan pasien dan mencegah kejadian yang tidak diinginkan terhadap pasien karena pihak keluarga sudah dapat menanganinya.

Langkah selanjutnya adalah melakukan komunikasi yang efektif . Komunikasi merupakan salah satu sarana untuk mengungkapkan perasaan, pendapat dari satu orang ke yang lainnya. Menurut Permenkes RI(2017) maksud dari komunikasi yang efektif adalah komunikasi yang tepat waktu karena jika dalam penanganan darurat tepat waktu sangat diperlukan, akurat karena keakuratan dari sebuah komunikasi akan berdampak bagi hal yang dilakukan selanjutnya, lengkap, jelas, dan mudah dipahami point ini sangat penting untuk mempermudah proses pengecekan pasien atau untuk keluarga pasien dapat mengkomunikasikannya kepada pihak medis yang bertugas.

Faktor pendukung selanjutnya adalah faktor finansial, Finansial merupakan hal yang penting karena untuk melakukan penanganan pada pasien tentunya membutuhkan biaya yang terkadang cukup tinggi dan mungkin terdapat beberapa keluarga yang mengalami masalah 
darurat terhadap kesehatan tetapi karena faktor finansial mereka tidak dapat membawanya kerumah sakit sehingga muncullah hal-hal yang tidak diinginkan terhadap pasien . Finansial menjadi salah satu faktor penting untuk mencegah kejadian yang tidak diinginkan terhadap pasien terutama dalam keadaan darurat.

Keluarga yang sudah berusaha untuk mencegah kejadian hal yang tidak diinginkan terhadap pasien tidakakan lengkap jika tidak terdapat bantuan dari tenaga medis. Salah satu yang dilakukan keluarga adalah membawa pasien ke tenaga medis yang terpercaya dan melakukan prosedur dan protokol yang sudah ditetapkan.

Menurut mentri kesehatan Republik Indonesia terdapat tujuh standar keselamatan pasien diantaranya adalah hak pasien, pasien dan keluarganya memiliki hak untuk mendapatkan informasi mengenai hasil pemeriksaan serta kemungkinan-kemungkinan apa saja yang dapat terjadi pada pasien. Kedua , mendidik pasien dan keluarganya hal ini sangat penting karena dengan mendidik pasien dan keluarga mengenai penyakit tersebut mereka dapat lebih waspada dan peduli tentang penyakit yang dimiliki oleh pasien.

Ketiga adalah keselamatan pasien dalam kesinambungan pelayanan. Keempat menggunakan metode-metode yang berguna untuk meningkatkan kinerja serta evaluasi dan juga melaksanakan program dalam rangka meningkatkan keselamatan pasien. Kelima adalah peran pimpinan dalam mendorong keselamatan dari pasien . Keenam mendidik seluruh staff dan karyawan yang ada akan pentingnya keselamatan dari pasien, terakhir adalah komunikasi yang dijadikan kunci antar staff dan karyawan dalam mencapai keselamatan dari para pasien.

Kedua elemen ini yaitu keluarga dan tenaga medis memegang peranan penting sehingga mereka tidak dapat berdiri sendiri dan harus saling membantu satu sama lain dalam penanganan pasien . Kedua elemen ini memiliki tujuan yang sama yaitu kesembuhan dari pasien dan menimalisir kejadian-kejadian yang tidak diinginkan kepada pasien melalui metode dan cara-cara yang telah dideskripsikan diatas.

\section{Kesimpulan}

Setiap manusia ingin memiliki kualitas hidup dan kesehatan fisik maupun mental yang baik tetapi hal itu tidak dapat diperoleh jika kita berdiri sendiri melainkan harus dengan lingkungan sekitar dan salah satunya adalah keluarga.

Keluarga menjadi elemen penting karena keluarga merupakan lingkungan terdekat kita dan kualitas hidup dengan keluarga dapat dinilai melalui lima aspek yaitu adaptasi, kemitraan , kasih sayang, pertumbuhan ,dan kebersamaan. Meskipun begitu , banyak orang yang masih memiliki kualitas hidup yang buruk serta penyakit. 
Dalam mengatasi penyakit serta kualitas hidup yang rendah maka lingkungan keluarga menjadi salah satu jalan untuk mengurangi beban pasien sehingga pasien terhindar dari hal-hal yang tidak diinginkan dapat dilakukan dengan cara tetap tenang, memberikan motivasi, komunikasi yang efektif, melakukan pengawasan dan konsultasi secara rutin, serta persiapan dalam hal finansial.

Peran penting tidak hanya dalam keluarga tetapi juga dengan bantuan tenaga medis yang memiliki visi dan misi yang sama yaitu penyembuhan dan mengurangi hal-hal yang tidak diinginkan terhadap pasien. Dengan melakukan point-point penting diatas maka pasien akan merasa aman sehingga proses penyembuhan juga dapat berjalan dengan lancar. 


\section{Daftar Pustaka}

Cecep Triwibowo, S. Y. (2 Juli 2016). HANDOVER SEBAGAI UPAYA PENINGKATAN KESELAMATAN PASIEN . Jurnal Keperawtan Soedirman, 11(2):76-80.

Firawati, A. P. (Maret-September 2012). PELAKSANAAN PROGRAM KESELAMATAN PASIEN DI RSUD SOLOK. 6(2):73-77.

Kamil, H. (n.d.). PATIENT SAFETY. 1(1):1-8.

Melia, Y. (Juli-Desember 2016). Upaya Keluarga Dalam Penyembuhan Pasien Penyakit Jiwa; Studi Pada Pasien Penyakit Jiwa di RSJ HB. Sa'anin Padang. Jurnal IImu Sosial Mamangan, 5(2):102-112.

Muhammad Erfansyah, D. R. (Februari 2020). HUBUNGAN FUNGSI PERAWATAN KESEHATAN KELUARGA DENGAN KEKAMBUHAN PADA PASIEN GANGGUAN JIWA DI WILAYAH KERJA PSUKESMAS MARTAPURA TIMUR. Healthy-Mu Journal, 34-40.

Najihah. (Juli 2018). BUDAYA KESELAMATAN PASIEN DAN INSIDEN KESELAMATAN PASIEN DI RUMAH SAKIT: LITERATURE REVIEW . Journal of Islamic Nursing, 3(1):1-8.

Pribadi, T. (April 2017). HUBUNGAN PERAN KELUARGA DENGAN DEPRESI PADA LANSIA DI KECAMATAN WAY HALIM BANDAR LAMPUNG TAHUN 2015. Jurnal Kesehatan Holistik, 11(2):82-89.

Retno A.Werdhani, E. P. (18 Februari 2017). Peran Keluarga dalam Pengelolaan Kasus di Layanan Primer Melalui Five Family Oriented Questions. 5(1):18-26.

Rosdiana. (2018). Identifikasi Peran Keluarga Penderita dalam Upaya Penanganan Gangguan Jiwa Skizofrenia. 174-180.

Simamora, R. H. (2019). Buku ajar pelaksanaan identifikasi pasien. Uwais Inspirasi Indonesia.

Susi Oktowaty, E. P. (1 September 2018). Hubungan Fungsi Keluarga Dengan Kualitas Hidup Pasien Penyakit Kronis Degeneratif di Fasilitas Kesehatan Tingkat Pertama. 4(1):1-6. 
